UDC 811:161.1-054.6

DOI: $10.17223 / 24109266 / 11 / 11$

\title{
CRITICAL THINKING AS A PREMISE FOR THE INTERCULTURAL COMPETENCE DEVELOPMENT
}

\begin{abstract}
A.V. Soboleva, A.J. Lomakina
Abstract. The intercultural orientation of education at the present stage is dictated by the objective conditions of the socio-economic and political context of the current century. Intercultural communicative competence is one of the main aspects of professional competence of a specialist. The intercultural orientation of language education is embodied in the objectives of the modern stage of development of the theory of teaching foreign languages. Language today is considered as a special tool for creating and interpreting the "image of the world", which provides the opportunity to "penetrate" into world culture, as well as the individual's awareness of their national and cultural identity, which in turn contributes to the formation and socialization of the student's personality. Such an understanding of the language, as well as the specificity of intercultural communication leads to the need to consider intercultural interaction from the perspective of mental processes. It is thinking that, being the highest stage of human knowledge, allows one to gain knowledge about such objects, properties and relations of the surrounding world that cannot be directly perceived through sensory perception. Thinking is an integral part and a special object of self-consciousness of a person, the structure of which includes understanding oneself as a subject of thinking, differentiation of "one's own" and "other's" thoughts, awareness of an unresolved problem as one's own, awareness of one's attitude to the problem. Critical thinking involves performing certain mental operations along with affective personality parameters. An analysis of intercultural communication from the perspective of cognitive personality parameters allows us to conclude that these parameters correlate with cognitive processes that form the essence of critical thinking and state the need for their interconnected development in the process of forming students' intercultural competence.
\end{abstract}

Keywords: critical thinking, intercultural competence, cognitive processes.

\section{Introduction}

Intercultural communication is a very ancient phenomenon, which appeared along with the formation of different cultures. With the development of mankind, the number of cultural exchanges increased, different peoples increasingly interacted with each other. Consequently, it became necessary to study other cultures. Nowadays, under the influence of globalization processes, intercultural interaction has become an integral part of the life of modern society. Today, integration processes have reached unprecedented proportions in almost all fields of life - international corporations are being 
created, the field of tourism is developing, migration processes are intensifying. It is obvious that there is a desire for closer cooperation between countries, for the deployment and deepening of international contacts.

However, even in the context of numerous integration and globalization processes, the modern diversity of cultures is not unified. Therefore, the study of the basics of intercultural interaction is necessary for every member of a modern society. Knowledge of the principles of intercultural interaction, understanding of its essence and features is important for both professional and personal development. Having at least a partial understanding of different cultures and understanding the differences between them, a person gets the idea of himself as a representative of one of these cultures, the nature and characteristics of this culture and its place in the world.

Such conditions require a personality capable of intercultural communication. The ability to carry out professional communication in foreign languages has become a necessity and one of the most demanded professional competencies which are required in the modern labor market. A professional communicant should be able to manage communication and overcome possible communication barriers, which can often complicate or impede the process of communication. It should be understood that communication is a complex process involving various aspects of the subjectivity of its participants.

Thus, linguistic education today is focused on intercultural communication, which is reflected in aims and objectives of the modern theory of foreign language teaching [1]. Language today is considered a special tool for the creation and interpretation of the "image of the world", which provides an opportunity to "penetrate" into the world culture, as well as for building individual's awareness of their national and cultural affiliation, which in turn contributes to the formation and socialization of the student's personality. Therefore, modern foreign language teaching programs should be oriented towards developing the ability of learners to perceive and process foreign communication constructions, taking into account the specific situation of communication, the speech task and communicative intention, which requires the development of student's communicative and cultural experience. The paper aims to prove that the development of intercultural competence skills should be based on the development of critical thinking skills, which to a great extend overlap and contribute to each other.

\section{Intercultural competence and thinking}

In the publications of Russian and foreign researchers there are different interpretations of the intercultural communicative competence concept, namely: 
- the ability that allows a person to go beyond his own culture and acquire the quality of a mediator of cultures without losing his own cultural identity [2];

- a set of background knowledge and the ability of their adequate application in a certain context on the basis of comparison of two or more cultures [3];

- a set of knowledge, skills and abilities by means of which an individual can successfully communicate with partners from other cultures both at the casual and professional levels [4];

- the ability to understand the situation, to acquire knowledge about the values and morals of another culture, as well as a certain potential for behavior in accordance with the values and morals adopted in the country of the studied foreign language [5].

Generally we see that the development of intercultural competence is aimed at the formation of an ability to communicate with the representatives of other cultures, using appropriate vocabulary in different contexts, as well as to understand the place and role of culture in the communication process. However the success of communication is also influenced by the nature of information that can be presented in speech explicitly or implicitly. To fully understand what he heard, the communicant needs to make certain conclusions in the process of statement perception. Let's consider, for example, the following short text: "Matt inherited a large amount of money. Berta loves diamonds and furs. Bertha was married to Matt". The text contains little actual information, but readers will likely conclude that Bertha married Matt for money and will now spend it on diamonds and furs, although such an interpretation may prove to be erroneous. Any message requires the addressee to fill in the gaps between the items of information in order to understand the implied meaning. That is why psychologists compare the process of mastering knowledge with the construction, in which new information is combined with what is already known to the recipient and the addressee. American psychologist Bruner gave a brief definition of thinking: "Going beyond the limits of available information". Understanding implicitness in speech by inference is the best example to support this definition [6].

Thinking is the highest level of human cognition; it allows you to get knowledge about such objects, properties and relationships of the world that cannot be directly perceived by sensory perception. Thinking is an integral part and a special object of person's self-consciousness, which includes the understanding of oneself as a subject of thinking, differentiation of "one's" and "other's" thoughts, awareness of the unsolved problem as one's own, awareness of one's attitude to the problem. One of the essential features of thinking is its unity with speech. Thinking is not "connected" with language, but expressed in it. Almost every word in a language is a concept and, mastering the language, a person thereby acquires the experience gained by 
many generations of people. Reflection of the most significant connections and relations between objects and phenomena of reality by thinking is also usually done in linguistic forms.

Thinking process begins with the appearance of any problem and is always aimed at solving that problem. The development of thinking contributes to the full mastery of a foreign language and understanding culture, as a student is involved in the learning process and is an active participant who seeks to show his vision of a problem. Along with the thinking process, the skills of acquiring foreign languages are developed, as students must not only express their thoughts creatively, show their understanding, share their thoughts, argue, but also be able to produce speech in a foreign language. Students not only listen, speak, read or write, they "absorb" the necessary material. Information becomes not a passive knowledge, but an active part of it. It is necessary for students to be sensitive to the language and culture they are learning, to strive to understand it and use it thoughtfully, accurately and clearly. Intercultural competence always involves the process of critical thinking as one of the main item.

\section{Critical thinking}

Critical thinking as an issue of the modern Russian education is quite relevant, since the traditional paradigm of education that has been preserved until recently was aimed primarily at transferring to students the conclusions of science by reporting facts, laws, principles and rules. Now there is a need to teach students to discover these principles and rules independently, i.e. to teach methods and ways of solving problems. In this respect critical thinking is recognized as an important competence for students to acquire in academic language.

In the XXI century, the concept of "critical thinking" has gained considerable interest of many researchers. Researchers have posed different definitions of the term "critical thinking", but they are all quite close in meaning. Thus Richard L. Elder \& W. Paul defines critical thinking as disciplined, self-directed thinking that illustrates improvements in thought that are appropriate to a specific way or area of thought [7]. Diana Halpern defines critical thinking as the use of cognitive techniques or strategies that increase the probability of achieving the desired outcome. All these definitions imply mental activity, which should be directed to solving a specific cognitive task [6].

Critical thinking is often mistaken for such thought processes as remembering, understanding, and intuitive thinking. It is important to understand that, despite the importance of memory development, memory is not thinking. The development of intelligence is more connected not with the exploitation of memory, but with the development of independent thinking. 
Understanding is just one of the preconditions of critical thinking. D. Kluster identifies five aspects that distinguish critical thinking [8]:

1. Critical thinking is independent thinking.

2. Information is the starting point, not the end point of critical thinking.

3. Critical thinking begins with asking questions and understanding the problems that need to be solved.

4. Critical thinking aimed at making a compelling argument.

5. Critical thinking is social thinking.

Facione defines critical thinking as the ability to reflect and withhold judgment before making a decision [9: 4]. The author concludes that critical thinking involves a set of cognitive skills, as well as a number of affective dispositions. Cognitive skills include interpretation, analysis, evaluation, inference, explanation and self-regulation. Analysis is concerned with investigating the relationships between different phenomena. It helps differentiate constituent components, their interaction and their correlations. It involves examining ideas, identifying key points, finding out arguments and supporting reasons, specifying and testing hypothesis, establishing the similarities and differences between two ways to the solution of a problem, comparing and contrasting. Interpretation involves understanding the meaning based on decoding and clarifying significant information. Inference deals with identification of relevant elements, stating a hypothesis and deducing the conclusions. It is based on interrogating evidence, guessing, choosing between different options and reaching conclusions. Evaluation is based on the credibility assessment of the information and contextual input a person perceives. Rendering the information involves explanatory skills which include "stating and justifying that reasoning in terms of the evidential, conceptual, methodological, criteria-logical, and contextual considerations upon which one's results were based" [Ibid: 6].

Along with interpretation, analysis, evaluation, inference, explanation and self-regulation skills, the author emphasizes that critical thinking is also based on the following dominant personal attributes:

- inquisitiveness with regard to a wide range of issues;

- concern to become and remain generally well-informed;

- alertness to opportunities to use critical thinking, trust in the processes of reasoned inquiry;

- self-confidence in one's own ability to reason;

- open-mindedness regarding divergent world views;

- flexibility in considering alternatives and opinions;

- understanding of the opinions of other people;

- fair-mindedness in appraising reasoning, honesty in facing one's own biases, prejudices, stereotypes, egocentric or sociocentric tendencies;

- prudence in suspending, making or altering judgments; 
- willingness to reconsider and revise views where honest reflection suggests that change is warranted.

Thus when a person thinks critically, he evaluates the results of his own mental activity - whether he has made the right decision or how successfully he coped with the task. Critical thinking also involves assessing the thought process itself - the reasoning that led to certain conclusions or the factors that were taken into account in the decision-making process. Critical thinking is also called directed thinking because it is aimed at achieving the desired result.

\section{Critical thinking and intercultural competence}

Intercultural competence is defined as an integrative personality quality, characterized by a set of communicative and cognitive resources, which manifest in a certain amount of knowledge, a number of skills and abilities [10: 58]. It allows a person to be an effective participant in intercultural communication. Intercultural competence development requires from a person a special characteristic of his personality that characterizes the valuebased, conscious attitude to intercultural communication as a way of understanding the world, its goals and objectives, the process and the result. It has been proved that the development of some cognitive parameters of a person's ability to interact in terms of intercultural communication is a necessary condition for the success of the intercultural communication competence development process [11]. These parameters serve as a prerequisite and indicator of personal development and his readiness for intercultural communication. Intercultural competence requires special state of volitional and emotional sphere that allows a personality to go beyond his culture and become an equal participant in the dialogue of cultures.

In intercultural communication each culture performs as a system of codes that extend to speech, relationships, social and cultural norms, etc. As a rule code systems of different cultures are not comparable to each other or at best comparable only to a limited extent. As a consequence, in the context of intercultural communication, despite the common language, the system of meanings, at least in the perspective of their cultural aspect, will have fundamental differences for the representative of this linguistic society and for those who use the language as a foreign language [2: 118]. This is due to the fact that communicants impose language and non-linguistic signs for each other, and the knowledge associated with these signs remains in their minds and is not available for direct observation by the communication partner. Cultural-specific knowledge should also be backed up with the ability to navigate in the phenomena of a different way of life (to recognize, to perceive, to interpret, to compare with one's own culture), to obtain and retrieve the information, to assimilate and operate with new knowledge. A successful 
intercultural communicant should be able to avoid current and prevent potential misunderstandings and conflicts arising on an intercultural basis, which becomes possible only due to positive attitude to another culture and its representatives. A certain state of psychological attitude towards cooperation with the representatives of a different culture as well as empathic perception of other forms of communicative behavior are also required. Cognitive and affective basis for effective intercultural interaction also rests on metacognition: open-mindness and readiness to get to know another culture and perceive new psychological, social and intercultural phenomena are always accompanied with the ability to monitor, analyze and evaluate oneself, control one's communicative performance and speech behavior.

The above discussion shows that the skills of critical thinking and intercultural communication competence overlap to a certain extent. A competent critical thinker will be able to cope with prejudices, he will manage to stay impartial in some challenging situation and overcome the obstacles that can impede intercultural communication, and, thus, they will be successful in intercultural cooperation and interaction.

\section{Conclusion}

Interest in critical thinking as a separate thought process has emerged not so long ago. Only in recent years educators have incorporated the improvement of mental abilities of students into training programs. Traditionally in Russian higher education it was supposed that adult students are already "able to think". Numerous studies have shown, however, that this assumption is wrong. Psychologists have found that only $25 \%$ of first-year students have the skills necessary for logical and abstract thinking - the type of thinking that is required, for example, to answer the question: "what happens if..." or to evaluate abstract ideas.

A collaborative research of educators around the world has led to the creation of so-called critical thinking technology. Such technology implied a system of strategies that combine the methods of teaching, regardless of the specific subject content. The technology allows students to master various ways of integrating information, forms their ability to develop their own opinion on the basis of understanding various experiences and ideas, to build conclusions and logical chains, to express their thoughts clearly, confidently and correctly in relation to others.

The development of critical thinking skills is also closely connected to the development of intercultural communication competence. In order to form students' intercultural competence it is necessary to develop their ability of critical thinking. Therefore, it is advisable to include the formation of critical thinking skills into the intercultural communication course. Students can be taught to think critically, if such objective is stated in the framework 
of a foreign language course. Critical thinking does not automatically appear as a side effect of conventional learning. Systematic efforts to improve thinking are required to achieve the expected effect.

\section{References}

1. Obdalova, O.A.: Inoyazychnoye obrazovaniye v XXI veke v kontekste sotsiokul'tur-nykh i pedagogicheskikh innovatsiy [Foreign language education in the XXI century in the context of socio-cultural and pedagogical innovations]. Natsional'nyy issledovatel'skiy Tomskiy gosudarstvennyy universitet. Tomsk (2014)

2. Yelizarova, G.V.: Kul'tura i obucheniye inostrannym yazykam: uchebnik [Culture and foreign language teaching: textbook] / SPb.: Soyuz (2001)

3. Furmanova, V.P.: Mezhkul'turnaya kommunikatsiya i lingvokul'turovedeniye $\mathrm{v}$ teorii $\mathrm{i}$ praktike obucheniya inostrannym yazykam [Intercultural communication and linguistic cultural studies in theory and practice of teaching foreign languages]. Saransk: Izd-vo Mordovskogo un-ta (1993)

4. Osnovy mezhkul'turnoy kommunikatsii: uchebnik dlya vuzov [Fundamentals of intercultural communication: textbook for universities] / Pod red. A.P. Sadokhina. M.: YUNITIDANA (2003)

5. Byram, M.: Teaching and assessing intercultural competence in language teaching. Multiligual Matters. Clevedon, pp. 34-127 (1997)

6. Halpern, D.: Psikhologiya kriticheskogo myshleniya [Psychology of critical thinking] / $\mathrm{SPb} .:$ Piter (2000)

7. Elder, P., Paul, R.: Defining Critical Thinking: Foundation for Critical Thinking (2008) URL: http://www.criticalthinking.org/pages/defining-critical-thinking/766

8. Kluster, D.: Chto takoye kriticheskoye myshleniye? [What is critical thinking?] // Peremena: Mezhdunar. zhurnal o razvitii myshleniya cherez chteniye i pis'mo. 4. pp. 36$40(2001)$

9. Facione, P.: Critical thinking: What it is and why it counts? Millbrae, CA: Peter A. Facione, Measured Reasons and the California Academic Press (2010)

10. Soboleva, A.V., Obdalova, O.A.: Cognitive readiness for intercultural communication as an essential component of intercultural communication. Language and Culture. 1 (5). pp. 55-62 (2015)

11. Soboleva, A.V., Obdalova, O.A.: The methodology of intercultural competence development on the basis of a cognitive style-inclusive approach. Procedia - Social and Behavioral Sciences. vol. 154. pp. 155-161 (2014)

\section{Information about the authors:}

Soboleva A.V. - Ph.D., Associate Professor, Tomsk State University (Tomsk, Russia). E-mail: alex_art@sibmail.com

Lomakina A.Ju. - Master's Degree Student, Tomsk State University (Tomsk, Russia). E-mail: annalomakina@sibmail.com 